\title{
DRAFT PREDICTION MODELS FOR SOIL ENGAGING TINES IN TWO SOILS OF RIO GRANDE DO SUL, BRAZIL
}

\author{
ANTÔNIO L. T. MACHADO ${ }^{1}$, CARLOS R. TREIN ${ }^{2}$
}

\begin{abstract}
The draft forces of soil engaging tines and theoretical analysis compared to existing mathematical models, have yet not been studied in Rio Grande do Sul soils. From the existing models, those which can get the closest fitting draft forces to real measure on field have been established for two of Rio Grande do Sul soils. An Albaqualf and a Paleudult were evaluated. From the studied models, those suggested by Reece, so called "Universal Earthmoving Equation", Hettiaratchi and Reece, and Godwin and Spoor were the best fitting ones, comparing the calculated results with those measured "in situ". Allowing for the less complexity of Reece's model, it is suggested that this model should be used for modeling draft forces prediction for narrow tines in Albaqualf and Paleudut.
\end{abstract}

KEYWORDS: chiselling, draft requirement, soil dynamics.

\section{PREDIÇÃO DO ESFORÇO DE TRAÇÃO PARA FERRAMENTAS DE HASTES COM PONTEIRAS ESTREITAS EM DOIS SOLOS DO RIO GRANDE DO SUL}

RESUMO: Os modelos de predição do esforço de tração, para ferramentas de hastes, em conjunto com a análise das teorias da relação ferramenta-solo, não têm sido estudados para os solos do Rio Grande do Sul. Buscou-se identificar os modelos matemáticos que permitam a obtenção, de forma precisa, da demanda de tração de ferramentas de hastes, para dois solos do Rio Grande do Sul. Foram estudados um Planossolo e um Argissolo Vermelho. Dentre os modelos estudados, aqueles propostos por Reece, também denominado "Equação Universal de Mobilização de Solo", por Hettiaratchi \& Reece, e Godwin \& Spoor, foram os que melhor ajuste proporcionaram. A comparação dos dados de esforço de tração medidos no campo, neste trabalho, com os calculados, utilizando-se destes modelos, apresentam bons resultados. Dada a menor complexidade de cálculo do modelo proposto por Reece, recomenda-se sua utilização como modelo matemático para predição de esforço de tração para ferramentas de hastes com ponteiras estreitas que estejam trabalhando num Planossolo ou Argissolo Vermelho.

PALAVRAS-CHAVE: escarificador, demanda de tração, dinâmica do solo.

\section{INTRODUCTION}

Agricultural soils are influenced by forces that change its physical condition. The magnitude of the changed condition is related to the amount of applied forces.

The interaction between soil and the soil engaging tool can be analyzed through soil parameters and the tool itself. Soil parameters are the shear stress, the cohesion and the angle of internal friction of the soil. The tool parameters considered are mainly its geometry and working depth. Such parameters are used in the development of theories and mathematical models that try to quantify and predict the tractive effort produced by tools. However, the lack of homogeneity of the soil associated with the complex way in which the ground breaks down, hampers the measurement of the interaction between tools and the acting forces. Knowledge of the distribution of forces acting on tools and their movement through soil has mainly two applications: assist in designing and

\footnotetext{
${ }^{1}$ Dr., Prof. Associado III, Universidade Federal de Pelotas, Faculdade de Agronomia Eliseu Maciel, Departamento de Engenharia Rural, Pelotas - RS, Brazil. Bolsista CNPq.

${ }^{2}$ Dr., Prof. Associado IV, Universidade Federal do Rio Grande do Sul, Departamento de Solos, Av. Bento Gonçalves, 7712, Porto Alegre - RS, Brazil.

Recebido pelo Conselho Editorial em: 13-10-2011

Aprovado pelo Conselho Editorial em: 30-8-2012
}

Eng. Agríc., Jaboticabal, v.33, n.1, p.167-175, jan./fev. 2013 
assessing the conditions and loads that the tool is subjected to during the force application and provide a way to quantify soil dynamic properties, when studying the mechanics of soil conditioning. According to GODWIN (2007) the type and degree of soil mobilization are the main factors used in selecting agricultural equipment; however, these should be considered in conjunction with the project requirements. The most important variables in the design and selection of suitable geometry for soil engaging tools are: depth/width ratio and the tine attack angle.

The knowledge of the forces on the tools generated while working, in conjunction with the soil- tool interaction mechanisms are important for the design of more effective elements of soil mobilization. The equations developed to predict traction efforts of narrow tools are based on rectangular models (GODWIN \& O’DOGHERTY, 2007). KARMAKAR \& KUSHWAHA (2006) point out that a better understanding of soil-tool interaction is obtained by correlating soil rheological behavior with its dynamic features, and mathematical solutions based on empirical and semi-empirical models were developed to describe this interaction.

MANUWA \& ADEMOSUN (2007), CONTE et al. (2008) and MANUWA (2009), note that the geometric aspects and the water content of the soil determine the tractive effort produced by narrow tillage tools, and that the ratio width/depth of the tool should be considered when going to the design of the equipment.

The geometry and depth of tillage tool affect significantly the tractive effort and interaction between both (CONTE et al., 2007).

The study of the forces that act on agricultural machinery and implements of tillage is one of the parameters that promote greater contribution to the solution of problems with rural mechanization, and the large amount of parameters involved in this process, which refer both to the machine on the ground, often hinder its assessment accurately.

The tractive effort and the time available to carry out agricultural tasks normally dictate the required power of a tractor on a farm. As the tractor is the largest capital investment in a property, the correct knowledge of tractive effort is necessary in making decision on agricultural machinery. The evaluation of information relating to tractive effort of tillage machines comes to be an important factor in the selection of equipment, being these data used to determine the tractor to be used and the cost and demand for energy used in this type of study.

Through this study, we tried to analyze the responses of soil against the transmission of tensions caused by working tools of stems with narrow tips (tillers). Also were sought mathematical models for calculating the tractive effort of narrow tillage tools, and check the one best suited to the situation of Rio Grande do Sul, Brazil.

\section{MATERIAL AND METHODS}

The study was developed in two locations onto two different soils, "Planossolo" (Albaqualf) and "Argissolo Vermelho" (Paleudult). Two different soil types were used to attempt to characterize the study of main soils of Rio Grande do Sul, Brazil.

The Albaqualf is located at the experimental field of the agricultural machinery Sector of

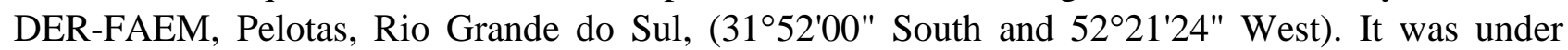
natural pasture after the land been tilled for about ten years. Before the present experimental study, the area was mowed, in order to facilitate the work of the chisel plough.

The Paleudult is located at the Experimental Station of the Agronomy Faculty of the UFRGS, in Eldorado do Sul, Rio Grande do Sul, (30²7'05"South and 51 $40^{\circ} 18^{\prime \prime}$ West). The area was with annual pasture with predominant vegetation of clover and ryegrass. Prior to the experiments the area was mowed, in order to facilitate the work of the chisel plough.

Experimental plots $50 \mathrm{~m}$ long were used in randomized blocked with four repetitions. Of each site, prior to the completion of the field work, undisturbed samples were taken at surface layer and 
at $20 \mathrm{~cm}$ deep, in order to carry out laboratory testing to obtain internal friction angle, soil cohesion, angle and soil-tine adhesion. The samples were saturated with water at the laboratory and submitted to tension table to prepare samples at three different water contents: dry samples, friable and plastic.

The physical parameters for characterization of soil such as, water content, texture, plasticity index, density, density of solids, total porosity, macroporosity, microporosity, soil were obtained through sampling, at the depth of $0,20 \mathrm{~m}$, for a total of nine samples per plot. The procedures for its determination were those recommended as standard in the area of soil physics and are described in MACHADO (2001).

The equipment used in the field consisted of a brand name John Deere tractor, 5600 frontwheel-drive, engine power of $53 \mathrm{~kW}$, total mass of $3835 \mathrm{~kg}$, rear tires $18.4-30 \mathrm{R} 1 \mathrm{t}$ and front tires 12.4-24 R1, inflated to $110 \mathrm{kPa}$ and $95 \mathrm{kPa}$, respectively. The selected gear was A3, up to $3.0 \mathrm{~km}$ per hour at 2,200 rpm and a Jan chisel plough with five shanks, Jumbo-Matic model, with narrow tips.

The dimensional characteristics of the shaft and tip of the chisel plough are as follows:

$\alpha=17^{\circ} 30^{\prime} ; \mathrm{W}=0,075 \mathrm{~m} ; \mathrm{W}_{\mathrm{h}}=0,032 \mathrm{~m} ; \mathrm{H}_{\mathrm{h}}=0,615 \mathrm{~m}$.

As the goal was to analyze soil-machine relationship just one of the shanks was used. It was run at $20 \mathrm{~cm}$ depth.

The data relating to tractive effort, working speed, working depth and total travelled distance was taken directly in the field, through the use of a portable data acquisition system for agricultural machines, developed at the electrical engineering faculty. The engine rotational speed, wheel rotation, shank deformation due to tractive effort (and hence, soil shear stress), working depth and real displacement with the use of a non powered wheel was measured concomitantly. This system is described in MACHADO et al. (2007).

The travel speed of the tractor, achieved through the use of a trailed wheel, remained close to $0,83 \mathrm{~m} \cdot \mathrm{s}^{-1}\left(3 \mathrm{~km} \cdot \mathrm{h}^{-1}\right)$, was considered the most suitable for these type of analysis, since higher speeds, depending on the soil characteristics at the time of field testing, would cause a poor quality in soil mobilization.

The soil parameters used in the mathematical models, such as cohesion, angle of internal friction of soil, soil-steel adhesion and friction were obtained in the laboratory, through the analysis of samples taken from the experimental plots. These soil characteristics may be found in Machado, 2001.

The equations for the mathematical models used to calculate the theoretical tractive effort were those used by MACHADO (2001). The mathematical models (equations) used are shown as 1 to 5 described below.

Model developed by Reece;

$\mathrm{H}=\mathrm{P} \operatorname{sen}(\alpha+\phi) \mathrm{CdW}+\cot \alpha$

Hettiaratchi \& Reece Model;

$\mathrm{H}=\left(\gamma \mathrm{gd}^{2} \mathrm{~N}_{\gamma}+\mathrm{CdN}_{\mathrm{c}}+\mathrm{qdN} \mathrm{N}_{\mathrm{q}}+\mathrm{C}_{\mathrm{a}} \mathrm{dN}_{\mathrm{ca}}\right) \mathrm{W} \operatorname{sen}(\alpha+\delta)+\mathrm{C}_{\mathrm{a}} \mathrm{dW} \cot \alpha+\mathrm{P}_{2} \operatorname{sen} \alpha$

McKyes \& Ali Model;

$H=P \operatorname{sen}(\alpha+\delta)+C_{a} d W \cot \alpha$

Godwin \& Spoor Model;

$\mathrm{H}=\left(\gamma g \mathrm{gN}_{\gamma}+\mathrm{CdN}_{\mathrm{c}}+\mathrm{C}_{\mathrm{a}} \mathrm{dN}_{\mathrm{ca}}+\mathrm{qdN}_{\mathrm{q}}\right)(\mathrm{W}+\mathrm{s}) \operatorname{sen}(\alpha+\delta)+\mathrm{C}_{\mathrm{a}} \mathrm{dW} \cot \alpha$ 
Model proposed by Perumpral et al.;

$$
\mathrm{H}=\left[1 / \operatorname{sen}(\alpha+\phi+\beta+\delta)\left\{-\mathrm{Facos}(\alpha+\phi+\beta)+2 \mathrm{SF}_{2} \cos \phi+\mathrm{Pssen}(\phi+\beta)+2 \mathrm{CF}_{2} \cos \phi+\mathrm{CF}_{1} \cos \phi\right\}\right.
$$

The statistical design used in the field experiment, were random blocks with four replications. The necessary field data was obtained directly with the data acquisition system and the data relating to the traction efforts was characterized as response variable. The force was measured through extensometers cemented directly on the stem of the chisel plough (MACHADO et al., 2007). The other variables were the travel speed of the machine, working depth and soil water content. The speed and depth of work were obtained through the above mentioned instrumentation and described by MACHADO et al. (2007). Statistical analyses was done comparing averages, in order to verify the existence of significant difference between the values of tractive effort obtained directly in the field and those predicted by different models.

\section{RESULTS AND DISCUSSION}

The data relating to the physical parameters for characterization of soils studied, Albaqualf and Paleudult are presented in Table1. The soils can be characterized as clay loamy soils. Values of soil density for both soils are very close.

Regarding Atterberg limits, both soils have similar values for the upper plasticity (LSP). However, in relation to the lower limit of plasticity (LIP) there is a difference, which provides a plasticity index twofold bigger for the Paleudult, when compared to Albaqualf. One can therefore say that the Paleudult presents less water storage capacity. Also, through the observation of the Atterberg limits, the water content can be characterized, from which soils change from elastic behavior to plastic and from this condition to the fluid state.

Through pretesting both soils for water content, it was found that, the application of a suction of $100 \mathrm{kPa}$, let enough water in the soil to characterize it as plastic, because the value obtained was below the upper limit of plasticity and higher than the lower limit of plasticity. When both soils were subjected to a suction of $330 \mathrm{kPa}$, water was drained letting the soil crumbling, below the lower limit of plasticity. When the samples were subjected to a suction of $15,000 \mathrm{kPa}$ soil reached the dry state.

TABLE 1. Physical parameters for soil characterization study (average values of nine replicates).

\begin{tabular}{lcc}
\hline Parameter & Albaqualf & Paleudult \\
\hline Texture $\left(\mathrm{kgkg}^{-1}\right)$ & & 0.672 \\
Sand & 0.620 & 0.150 \\
Silt & 0.263 & 0.178 \\
Clay & 0.117 & \\
\hline Density $\left(\mathrm{kgm}^{-3}\right)$ & & 1,570 \\
Soil density & 1,513 & 2,636 \\
Density of solids & 2,695 & \\
\hline Atterberg limits de $\left(\mathrm{kgkg}^{-1}\right)$ & & 0.226 \\
\hline Upper limit of plasticity & 0.217 & 0.139 \\
Lower limit of Plasticity & 0.181 & 0.087 \\
Plasticity index & 0.036 & \\
\hline Porosity (m & \\
\hline Macroporositye & & 0.149 \\
Microporositye & & 0.268 \\
Total Porosity & 0.086 & 0.418 \\
\hline
\end{tabular}


It turns out that the soil microporosity is higher than macroporosity in both soils. The Paleudult, however, shows a higher macroporosity and lower microporosity when compared to the Albaqualf. Although the macro and microporosity values are different, the total porosity values are quite close in both soils.

By plotting curves relating $\tau$ to $\sigma$ a straight line equation was attained enabling the calculation of the angle of internal friction and cohesion.

The values of tractive effort for a chisel shank working at the average depth of $0.19 \mathrm{~m}$, on an Albaqualf and the values obtained by calculation with use of mathematical models, are in table 2 .

TABLE 2. Draught for Albaqualf, depending on the working depth, (field testT1) and results obtained using mathematical models.

\begin{tabular}{clllll}
\hline & \multicolumn{4}{c}{ Depth $(\mathrm{m})$} & \multicolumn{2}{c}{ Medium } \\
\cline { 2 - 6 } & 0.16 & 0.18 & 0.20 & 0.20 & 0.19 \\
\cline { 2 - 6 } McKeys \& Ali & \multicolumn{4}{c}{ Tractive effort $(\mathrm{kN})$} \\
\cline { 2 - 6 } & 0.75 & 0.75 & 0.87 & 0.94 & $0.83 \mathrm{a}$ \\
\hline Hettiaratchi \& Reece & 1.80 & 2.00 & 2.38 & 2.71 & $2.22 \mathrm{~b}$ \\
\hline Reece & 1.95 & 2.14 & 2.50 & 2.71 & $2.33 \mathrm{~b}$ \\
\hline Campo T1 & 2.41 & 3.38 & 3.04 & 3.83 & $3.17 \mathrm{bc}$ \\
\hline Godwin \& Spoor & 3.32 & 3.75 & 4.40 & 4.89 & $4.09 \mathrm{c}$ \\
\hline Perumpral et al. & 4.55 & 5.28 & 6.45 & 7.19 & $5.87 \mathrm{~d}$ \\
\hline
\end{tabular}

C.V. $=12.16 \%$. Values followed by the same letter, do not differ by Tukey test to the $1 \%$ level of significance.

The coefficient of variation of $12.16 \%$ demonstrates adequate experimental precision. The analysis of variance showed that there was significant difference between mathematical models and field test, with respect to tractive effort, which is proven by the analysis of the mean differences laid down in tables 2 and 3.

From all the models only those proposed by Reece and by Hettiaratchi \& Reece are presenting results of tensile stress that are equal to each other and close to the obtained in the field test as there is no significant difference with respect to the mean values obtained from these models and field test $\mathrm{T} 1$.

There is no significant difference between the mean value of tractive effort, obtained with the model proposed by Godwin \& Spoor and the one verified in the field test T1.

The values of draught for a chisel shank working at an average depth of $0.21 \mathrm{~m}$, (field test T2) and the calculation obtained through the use of mathematical models, are grouped in table 3.

TABLE 3. Draught for Albaqualf, depending on the working depth, (field test T2) and results obtained using mathematical models.

\begin{tabular}{cccccc}
\hline & \multicolumn{4}{c}{ Depth $(\mathrm{m})$} & \multicolumn{2}{c}{ Medium } \\
\cline { 2 - 6 } & 0.17 & 0.20 & 0.21 & 0.26 & 0.21 \\
\cline { 2 - 6 } McKeys \& Ali & \multicolumn{3}{c}{ Tractive effort $(\mathrm{kN})$} \\
\cline { 2 - 6 } & 0.65 & 0.92 & 0.94 & 1.10 & $0.90 \mathrm{a}$ \\
\hline Reece & 2.11 & 2.50 & 2.69 & 3.08 & $2.60 \mathrm{ab}$ \\
\hline Hettiaratchi \& Reece & 1.62 & 2.56 & 2.81 & 3.74 & $2.68 \mathrm{abc}$ \\
\hline Campo T2 & 2.04 & 3.94 & 4.27 & 4.54 & $3.70 \mathrm{bc}$ \\
\hline Godwin \& Spoor & 2.95 & 4.67 & 5.00 & 7.05 & $4.92 \mathrm{~cd}$ \\
\hline Perumpral et al. & 4.81 & 6.72 & 7.40 & 9.76 & $7.17 \mathrm{~d}$ \\
\hline
\end{tabular}

$\overline{\text { C.V. }}=19.34 \%$. Values followed by the same letter, do not differ by Tukey test to the $1 \%$ level of significance. 
The coefficient of variation of $19.34 \%$ demonstrates adequate experimental precision. In the same way as for the field test T1, T2 field test for the analysis of variance showed that there was significant difference between mathematical models and field test, with respect to tractive effort, which is proven by the analysis of the differences of the averages in table 3.

The example of what has occurred within the field test T1, the models proposed by Reece and Hettiaratchi \& Reece are those with traction effort closer to that obtained in the real situation, since the statistical test demonstrates that there is no difference, in relation to the average values of tractive effort, obtained by these models and field test $\mathrm{T} 2$.

Again, with regard to the model proposed by Godwin \& Spoor there is no difference, in relation to the average amount of tractive effort, obtained by its use and that checked in field test $\mathrm{T} 2$.

Due to the fact of the models proposed by Reece and Hettiaratchi \& Reece were those that allowed values of tractive effort closer to the field situation, we can say that it is possible to use them, as forecasting model of tractive effort of narrow tools for Albaqualf. As the model proposed by Reece, also called "Universal Equation of soil Mobilization", is the quite simple and, therefore, easier to calculate than that proposed by Hettiaratchi \& Reece, it is quite plausible to use it as a prediction model of tractive effort for narrow tools working on Albaqualf.

In tables 4 and 5 are set out the efforts of traction, obtained in field testing T1 and T2 on Paleudult together with the values calculated using models for prediction of tractive effort which are the object of study of this research.

Through the analysis of variance significant difference occur between the mathematical models and field test, with respect to tractive effort, proven by the analysis of the differences of the averages (table 4). The coefficient of variation of $17.21 \%$ demonstrates adequate experimental precision.

The models proposed by Reece and Hettiaratchi \& Reece, show draft values close to those achieved in the real working situation. The statistical test also demonstrates no difference, with respect to the mean values of the models proposed by Reece and Hettiaratchi \& Reece and those obtained in field test T1. Also, when one analyzes these models, it can be seen that these do not differ with respect to the value of tractive effort at a significance level of $1 \%$.

TABLE 4. Draught for Paleudult, depending on the working depth, (field test T1) and results obtained using mathematical models.

\begin{tabular}{crrrrr}
\hline & \multicolumn{4}{c}{ Depth $(\mathrm{m})$} & \multicolumn{2}{c}{ Medium } \\
\cline { 2 - 6 } & 0.18 & 0.3 & 0.24 & 0.25 & 0.23 \\
\cline { 2 - 6 } McKeys \& Ali & \multicolumn{4}{c}{ Tractive effort $(\mathrm{kN})$} \\
\cline { 2 - 6 } & 1.70 & 2.21 & 2.31 & 2.41 & $2.16 \mathrm{a}$ \\
\hline Reece & 4.44 & 5.81 & 6.08 & 6.34 & $5.67 \mathrm{ab}$ \\
\hline Campo T1 & 6.16 & 6.37 & 9.29 & 9.10 & $7.73 \mathrm{abc}$ \\
\hline Hettiaratchi \& Reece & 7.26 & 11.59 & 12.30 & 13.56 & $11.18 \mathrm{bcd}$ \\
\hline Godwin \& Spoor & 9.41 & 15.23 & 16.59 & 18.01 & $14.81 \mathrm{de}$ \\
\hline Perumpral et al. & 12.68 & 20.00 & 21.66 & 23.39 & $19.43 \mathrm{e}$ \\
\hline
\end{tabular}

C.V. $=17.21 \%$.Values followed by the same letter, do not differ by Tukey test to the $1 \%$ level of significance.

In the calculation of the models, soil physical parameters and working depth obtained in the field were used.

The coefficient of variation of $27.53 \%$ demonstrates reasonable experimental precision. The analysis of variance shows that, according to the $\mathrm{F}$ test, there is no significant difference at $1 \%$ probability level, between mathematical models and the field test, with respect to tractive effort, which is proven by the analysis of the differences of means laid down in Table 5. 
As it happened in field test T1 draught values attained using Reece and Hettiaratchi \& Reece models, again show values closer to those obtained field test T2. However, it can be seen that the tractive effort calculated using the model proposed by Godwin \& Spoor did not differ significantly at the $1 \%$ level of significance. Either from field test T2, or from those models proposed by Reece and Hettiaratchi \& Reece.

TABLE 5. Draught for Paleudult, depending on the working depth, (field testT2) and results obtained by the use of mathematical models.

\begin{tabular}{cccccc}
\hline & \multicolumn{3}{c}{ Depth $(\mathrm{m})$} & \multicolumn{2}{c}{ Medium } \\
\cline { 2 - 6 } & 0.12 & 0.15 & 0.16 & 0.21 & 0.19 \\
\cline { 2 - 6 } McKeys \& Ali & \multicolumn{4}{c}{ Tractive effort (kN) } \\
\cline { 2 - 6 } & 1.21 & 1.22 & 1.38 & 1.90 & $1.43 \mathrm{a}$ \\
\hline Reece & 3.33 & 3.37 & 3.91 & 4.52 & $3.78 \mathrm{ab}$ \\
\hline Campo T2 & 2.14 & 3.77 & 3.73 & 7.08 & $4.18 \mathrm{abc}$ \\
\hline Hettiaratchi \& Reece & 3.08 & 4.43 & 5.04 & 9.25 & $5.43 \mathrm{abcd}$ \\
\hline Godwin \& Spoor & 4.40 & 5.67 & 6.64 & 11.66 & $7.09 \mathrm{bcde}$ \\
\hline Perumpral et al. & 6.65 & 8.06 & 9.77 & 14.62 & $9.78 \mathrm{de}$ \\
\hline
\end{tabular}

C.V. $=27.53 \%$. Values followed by the same letter, do not differ by Tukey test to the $1 \%$ level of significance.

Therefore it should be noted that, for the Paleudult used in the test, the best suited predictive models of tractive effort would be those proposed by Reece and Hettiaratchi \& Reece.

The model proposed by Reece, being simpler than that proposed by Hettiaratchi \& Reece, also was the one that presented values of tractive effort closer to those obtained in field testing T1 and T2. The best prediction to the necessary draught for narrow tine is therefore attained using Reece's model.

Through the analysis of Tables 2, 3, 4 and 5, it can be seen that the models used for tractive effort provide significantly different results. These can be assigned to the fact that the analysis of the phenomenon of soil mobilization by narrow tools, as evidenced in each model is diverse, leading to differentiation of components and variables of the equation; in this way the different results were expected beforehand.

It turns out that the models that allow a better fit of calculated value of tractive effort with those obtained in the field, both for Albaqualf as for the Paleudult, are those proposed by Reece, Hettiaratchi \& Reece and Godwin \& Spoor, which describe with more accuracy the phenomenon.

Invariably, for the two studied soils, the model proposed by McKyes \& Ali, which is based on the model proposed by Godwin \& Spoor, with simplifications considering that the breaking line in front of the tine is straight forward, gave lower values of tractive effort. On average, the predicted force needed to break the Albaqualf was less than $74 \%$ of the real measured force, while for the Paleudult; the draft predicted by this model was, on average, $69 \%$ lower than that obtained in the field. These comments are not in accordance with those made by McKYES \& DESIR (1984), which reports that, in their analyses, the model proposed by McKyes \& Ali overestimated the tractive effort at $14.6 \%$.

In contraposition, the model proposed by Perumpral et al. predicted higher values for the tractive effort (over 70 and 90\% for Albaqualf), 167 and 142\% in the Paleudults. This may be due to the fact that these authors sought to establish a model that is mathematically based on several more widely assumptions, including that the soil is isotropic and homogeneous, that soil rupture surface forward and to the side of the tool is flat, that the forces of friction and adhesion are uniformly distributed on the surfaces of rupture and that the acceleration forces on the tool are zero and that the disruption of the soil in the center of its area of mobilization is the same as it is across the width of the tool. 
The result obtained with respect to the model proposed by Hettiaratchi \& Reece showed $27.5 \%$ variation for the Albaqualf, comparing the calculated value to the measured one in the prediction of tractive effort, and around and $37 \%$ for the Paleudult, which somewhat contrasts with observations of GODWIN \& SPOOR (1977), stressing that the above-mentioned model gives errors on the order of $50 \%$ when used for narrow tools.

Analyzing individually these models, it is observed that the one proposed by Reece, who uses similar soil mobilization mechanisms, in many respects, to the simplified procedure for the calculation of the load capacity of the soil to foundations, described by Terzaghi, comes to be less complex. This fact together with its excellent predictability of tractive effort makes it quite attractive, when predicting the tractive effort of narrow tools, either with an Albaqualf or Paleudults.

The results presented here, are not in complete agreement with those obtained by the aforementioned authors, whose surveys were carried out on different soils and different soil conditions than those used in the present work, reveals the importance of studying the prediction models of tractive effort and its applicability to soils of Rio Grande do Sul, Brazil.

\section{CONCLUSIONS}

The draught force prediction models developed by Reece, Hettiaratchi \& Reece and Godwin \& Spoor were those that provided the best fits to field tests conducted on Albaqualf and Paleudult.

The model proposed by Reece is less complex and can be used to predict the tractive effort of narrow tools.

The results of this study came to different outcomes than those obtained by authors who have worked with other soil types, and show the importance of studying the draught forces and its applicability to soils of Rio Grande do Sul, Brazil.

\section{LIST OF SYMBOLS}

C- index of soil cohesion;

$\mathrm{Ca}$ - soil-metal adhesion index;

CF1 - a cohesive force on the breaking line;

CF2 - a cohesive force on the sides;

d - depth;

Fa - adhesion strength;

$\mathrm{g}$-acceleration due to gravity;

$\mathrm{H}$ - tractive force;

$\mathrm{H}_{\mathrm{h}}$ - height of the tool shank.

$\mathrm{No}_{\mathrm{ca}}$ - index factor of soil adhesion.

$\mathrm{N}_{\gamma}$ - soil density factor;

$\mathrm{N}_{\mathrm{c}}$ - index of soil cohesion;

$\mathrm{No}_{\mathrm{q}}$ - vertical surcharge;

$\mathrm{P}$ - soil reaction in the Center above the critical depth;

Ps - wedge weight of soil;

$\mathrm{P}_{2}$ - force that mobilizes the lateral areas;

$\mathrm{Q}$ - surcharge of vertical pressure acting on the surface of the soil; 
$\mathrm{SF}_{2}$ - friction force provided by the side wedges;

W - tool width;

$\mathrm{W}_{\mathrm{H}}$ - width of the shaft of the tool;

$\alpha$ - angle of the tool;

( $\beta$ ) - soil failure angle to the front of the tool;

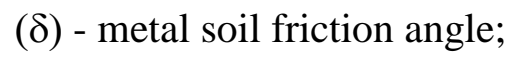

( $\phi)$-angle of internal friction of soil;

$\gamma$ - soil density;

$\sigma$ - normal voltage;

$\tau$ - maximum shear strain of soil.

\section{REFERENCES}

CONTE, O.; LEVIEN, R.; TREIN, C. R.; CEPIK, C.T.C.; DEBIASI, H. Demanda de tração em haste sulcadora na integração lavoura-pecuária com diferentes pressões de pastejo e sua relação com o estado de compactação do solo. Engenharia Agrícola, Jaboticabal, v.27, n.1, p.220-228, 2007.

CONTE, O.; LEVIEN, R.; TREIN, C. R.; MAZURANA, M.; DEBIASI, H. Resistência mecânica do solo e força de tração em hastes sulcadoras de semeadoras-adubadoras em sistema de integração lavoura-pecuária. Engenharia Agrícola, Jaboticabal, v.28, n.4, p.730-739, 2008.

GODWIN, R.J. A review of effect of implement geometry on soil failure and implement forces. Soil \& Tillage Research, Amsterdam, v.97, p.331-340, 2007.

GODWIN, R.J.; O`DOGHERTY, M. J. Integrated soil tillage forces prediction models. Journal Terramechanics, Amsterdam, v.44, p.3-14, 2007.

GODWIN, R. J.; SPOOR, G. Soil failure with narrow tines. Journal of Agricultural Engineering Research, Silsoe, v. 22, p.213-228, 1977.

KARMAKAR, S.; KUSHWAHA L. R. Dynamic modeling of soil-tool interaction: an overview from a fluid flow perspective. Journal Terramechanics, Amsterdam, v.43, p.411-425, 2006.

MACHADO, A. L. T. Previsão do esforço de tração para ferramentas estreitas em solos do Rio Grande do Sul. 2001. 172 f. Tese (Doutorado em Ciência do Solo) - Faculdade de Agronomia, Universidade Federal do Rio Grande do Sul, Porto Alegre, 2001.

MACHADO, A. L. T.; TREIN, C. R.; BRITO, R. M. Sistema eletrônico para aquisição de dados em máquinas agrícolas. Revista Brasileira de Engenharia de Biossistemas, Campinas, v.3, p.255-264, 2007.

McKYES, E., DESIR, F. L. Prediction and field measuraments of tillage tool draft forces and efficiency in cohesive soils. Soil \& Tillage Research, Amsterdam, n. 4, p.459-470, 1984.

MANUWA, S. J. A performance evaluation of tillage tines operating under different depths in a sandy clay loam soil. Soil \& Tillage Research, Amsterdam, v.103, p.399-405, 2009.

MANUWA, S. J.; ADEMOSUN, O.C. Draught and soil disturbance of model tillage tines under varying soil parameters. Agricultural Engineering International: The CIGRE Journal, v.9, p.1-18, 2007. 